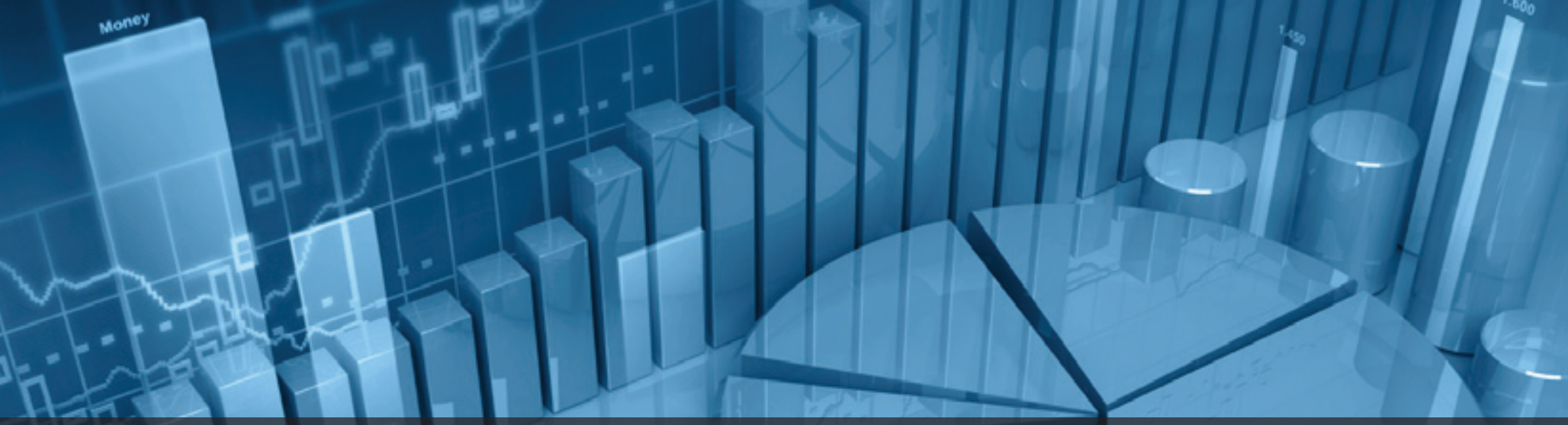

\title{
Trading and Fat Tails
}

\section{By Robert I. Webb}

Robert I. Webb is the Paul Tudor Jones II Research Professor at the Mclntire School of Commerce at the University of Virginia in Charlottesville, Virginia, USA.

Sudden, large price changes periodically occur in speculative markets. Many of these large price moves simply reflect the market's reaction to new fundamental economic information-- as financial theory would predict. However, some of the most extreme price moves-often characterized (albeit incorrectly) as "Black Swans" in popular parlance--reflect more the predictable behavior of traders in certain situations or poorly designed market microstructures than the arrival of new fundamental information. These trading-induced price moves have important implications for practitioners, policymakers and academics alike.

Keywords: fat tails; extreme events; stock price behaviour

\section{The Behavior of Speculative Prices}

Most changes in speculative prices follow simple time series processes. Indeed, empirical observations by Working (1934); Kendall (1953); and Roberts (1959) that changes in various speculative prices appeared to fluctuate randomly preceded the development of a theory to explain why they should (Samuelson, 1965). The notion that changes in speculative prices respond only to the arrival of new information in an efficient capital market as Fama (1965) and Ross (1989) have argued remains a central tenet of modern financial theory.

The observation by Mandelbrot (1963) that the distributions of changes in many speculative price series were characterized by leptokurtosis (i.e., both peakedness and fat tails) meant that the probability of extreme events was greater than what would exist if security returns were lognormally distributed. Put differently, even extreme price moves should be the result of the market's response to the arrival of new fundamental information in an efficient capital market.
To be sure, there is a considerable literature in financial economics that argues that changes in speculative prices are the result of factors other than the arrival of new fundamental economic information. These factors range from noise (Black, 1986) to the bid/ask bounce (Marsh and Rosenfeld, 1986) to positive feedback and noise trading (DeLong et al., 1989, 1990a, 1990a) to large orders or order flow (e.g., Evans and Lyons, 2002) among others. Not surprisingly, apparent bubbles and crashes in speculative prices have spawned a large literature that seeks to explain them or deny their existence. Implicit in much of this literature is the belief by many observers of the central role played by "excessive speculation." Of course, as Miller (1988) has pointed out, the term requires a benchmark level of speculation against which to compare it. There is also a nascent literature on predatory trading that illustrates how the actions of some traders can exploit the problems of large distressed traders, thereby exacerbating a price move (Brunnermeier and Pedersen, 2005, Chamley, 2003 and Corsetti et al., 2004 among others). 


\section{Trading-Induced Price Changes- Predatory Trading}

Speculative prices react to news. News can consist of perceived fundamental information or noise--nonfundamental information that affects prices. Prices may also react to the actions of traders without news per se such as from large orders or positive feedback trading. The nature and size of trading-induced price moves are perhaps best illustrated through various examples. For the convenience of exposition, trading-induced price moves will be dichotomized into those arising from predatory trading and those arising from flawed market microstructures.

The U.S. stock market crash of October 19, 1987 is well known even if the cause is still unclear. Jackwerth and Rubinstein (1996) point out that the $29 \%$ decline in the S\&P 500 stock index futures price (the cash market declined less) was equivalent to a 27 standard deviation move assuming that changes in stock prices are lognormally distributed and annualized volatility averages $20 \%$. The probability of a 27 standard deviation move is a $10^{-160}$ event or virtually impossible. Regardless of whether one regards the crash as trading-induced or the reaction to the arrival of fundamental information the question arises as to whether it could happen again. Or, rather, did it happen again in the USA in 1987? The answer is yes.

\subsection{Extreme Events: October 22, 1987}

On Wednesday, October 21, 1987, the December 1987 delivery Standard \& Poor's 500 stock index futures contract closed at 258.25 on the Chicago Mercantile Exchange. A large (5,000 contract) sell order attributed to George Soros whose fund was rumored to be in trouble precipitated a sharp selloff in S\&P 500 stock index futures prices at the opening the next day. Suppose that you were a trader on the floor of the Chicago Mercantile Exchange. How would you react to the large sell order given the rumors of a large trader in trouble? Would you buy or sell?

The November 2, 1987 issue of Barron's recounts the natural reaction of other traders:

\section{"... The other pit traders, picking up the sound of a whale} in trouble, hung back, but circled the prey. The offer went from 230 down to 220 to 215 to 205 to 200. Then, the pit traders attacked. The Soros block sold from 195 to 210. The spiral was ghastly. It was Soros's block and not program trading that drove the futures to a cash discount some 50 points, or 20\%, below the cash value of the S\&P contract. ..."
Keep in mind that each full point was worth $\$ 500$ per contract at the time and that prior to the crash on Monday the contract usually traded in $\$ 25$ increments. The opening offer at 230 was $\$ 14,125$ per contract below the previous close. Trades at 195 (the opening and lowest price of the day) were $\$ 31,625$ per contract lower than Wednesday's closing price. And, with interest rates exceeding dividend rates stock index futures prices should exceed corresponding cash market prices if the cost of carry model of futures prices is correct.

The market had an exceptionally wide opening range of 195 to 202 or $\$ 3500$. Soros suffered a loss in excess of $\$ 200$ million. Barron's (1987) reported: "...The discount on the 5,000 contracts represented some $\$ 250$ million. [Soros] covered there, as did a number of local traders who made millions off the immediate snapback in price. The contract that day closed at 244.50 , or some $\$ 222$ million higher, based on Soros's position..."

Note that the magnitude of the decline in the value of the S\&P 500 stock index futures contract from Wednesday's close to Thursday's opening was $21.8 \%$ to $23.8 \%$---roughly the same size as the decline in the cash S\&P 500 stock index on Monday, October 19, 1987. Note also that the effect of the large sell order was largely limited to the S\&P 500 stock index futures market. Unlike Monday, October 19th, prices in the stock market did not fall very much so that, at one point, the December ' 87 S\&P 500 stock index futures contract was trading at a 50 point discount to the cash index. The huge discount was a result, in part, of the inability to easily do index arbitrage in the wake of the crash.

\subsection{Extreme Events: October 7, 1998}

On Wednesday, October 7, 1998, the dollar fell sharply against the yen. At one point, the dollar was down almost 12 yen or over $9.15 \%$ intraday. This is an incredible move for the exchange rate between the currencies of two developed economies. The catalyst for this huge move was simply the unwinding of massive short yen and yen-carry positions by hedge funds and other market participants-and the belief that some major hedge funds were in trouble.

Once again, the rumor of some key traders attempting to unwind a large position sparked a change in the actions and strategies of other traders. Tiger Management-at the time the largest hedge fund in the world-was rumored to have lost over $\$ 1$ billion on that day from its short yen positions. 


\subsection{Extreme Events: October 26, 2008}

The Sunday, October 26, 2008 announcement by Porsche that it controlled almost three-quarters of $\mathrm{VW}$ shares directly or indirectly through stock holdings and call options sparked panic buying by short sellers. ${ }^{3}$ This resulted in a $146 \%$ rise in VW's stock price on Monday, October 27 , 2011 and, as Xydias (2008) notes, another 93\% rise intraday on Tuesday, October 28, 2008 to a high of $€ 1005$ per share or over 5 times the closing price the previous Friday. For one brief shining moment, in the midst of a global financial crisis and widespread recession, VW was the largest company in the world in terms of market capitalization. Here was a large price move that was entirely related to one market participant gaming the system rather than the arrival of fundamental new information.

\subsection{Extreme Events: Speculative Attacks}

The above events were examples of traders behaving in a very opportunistic fashion-(i.e., taking advantage of traders in distress). There are numerous similar instances. But do cases exist where traders attempt to make things happen (i.e., create distress for market participants by pushing prices in a certain direction)? The answer is yes and such situations arise during speculative attacks. Webb (2007) reports that in 1997, some hedge funds tried to break the link of the HK dollar to the US dollar. This induced considerable volatility in interest rates and HK equity prices. The volatility spilled over to the USA on October 27, 1997 when US equity prices fell over $7 \%$. Notwithstanding the volatility in equity and fixed income prices the link of the Hong Kong dollar to the U.S. dollar held as the hedge funds ran out of Hong Kong dollars to short. The hedge funds would have made a fortune had they sold Hong Kong stocks before the speculative attack. The hedge funds learned from their errors, borrowed HK\$30 billion via a currency swap and tried again in 1998. This time the hedge funds sold Hong Kong stock index futures in advance of the speculative attack on the Hong Kong dollar. Joseph Yam (1998), head of the Hong Kong Monetary Authority (Hong Kong's de facto central bank) at the time states: "We estimate that the hedge funds involved had amassed in excess of HK\$30 billion in currency borrowings at an interest cost of around HK\$4 million a day. They also held an estimated 80,000 short [Hang Seng stock index futures] contracts, which translated into the following calculation: for every fall of 1,000 points in the Hang Seng [stock] index they stood to make a profit of HK\$4 billion. ... If they could have achieved it within 100 days they would have netted HK\$3.6billion...."

The preceding examples demonstrate that you do not need electronic trading platforms and high frequency traders to have substantial trading-induced price changes. Predatory trading can precipitate large price moves.

\section{Trading-Induced Price Changes- Flawed Market Microstructures}

Another source of sudden large price changes arises from the actions of high frequency and algorithmic traders in continuously open electronic markets without designated market makers. Consider the following examples.

\subsection{May 6, 2010 "Flash Crash."}

On May 6, 2010, the Dow Jones Industrial Average suddenly fell over 600 points in less than five minutes only to recover most of the 600-point loss within minutes. ${ }^{4}$ An interagency task force assigned to investigate the cause of the flash crash (Securities Exchange Commission (2010)) concluded it was caused by a fundamental trader who submitted an order to sell 75,000 e-mini S\&P 500 stock index futures contracts without price or time limits. About 6 percent of the total value of the U.S. stock market was wiped out in moments without any apparent reason only to recover shortly thereafter.

While the flash crash in equity prices is well known fewer people are aware of even larger flash crashes in commodity markets. Moreover, it is doubtful that any lessons learned from the May 6, 2010 Flash Crash were implemented as these lesser-known flash crashes occurred in 2011.

\subsection{March 1, 2011 "Flash Crash" in Cocoa Futures}

On March 1, 2011, May delivery cocoa futures fell 12.5\% in less than a minute on the Intercontinental Commodity Exchange only to quickly rebound and close down $2.5 \%$ for the day. Once again, the presumed culprit was a large sell order.

\subsection{February 3, 2011 "Flash Crash" in Sugar Futures}

On February 3, 2011, March delivery sugar futures prices suddenly plunged. The decline in cocoa futures prices mentioned earlier was slow compared with the nearly $6 \%$ plunge in March sugar futures prices in a single second. The presumed source in this case was algorithmic trading.

\subsection{June 8, 2011 Natural Gas Futures Flash Crash}

On June 8, 2011, July delivery New York Mercantile Exchange natural gas futures suddenly fell over $8 \%$ in after regular trading hours trading only to recover in a few seconds. Algorithmic trading was blamed. 


\subsection{November 25, 2011 Automated Trading Gone} Wild

Reuters News (Spicer, 2011) reported on November 25, 2011 that a high frequency trading firm was fined by the CME for losing control over their trading algorithms on three occasions. The firm's "buying on February 3, [2010] sparked a frenzied $\$ 1$ surge in oil prices late that day as the computer program sent thousands of orders per second, racking up a million-dollar loss for the firm." Although this does not constitute an extreme price move it does illustrate the potential of uncontrolled trading algorithms to increase volatility in speculative prices.

\subsection{Policy Responses to Automated Trading Induced Volatility}

Bloomberg News (McCormick, 2011) reported on March 17, 2011: "The yen soared 4.5 percent in 26 minutes as markets closed in New York and re-opened in Asia amid speculation automated trades to limit losses were taking place. The yen reached 76.36 per dollar before erasing its gains." The sharp rise in the yen was one factor that precipitated an intervention in the currency markets by G-7 central banks.

\section{Implications}

Trading induced price changes may arise from: predatory trading; positive feedback trading; flawed market microstructure or trading strategies; erroneous orders; large orders in illiquid markets. These changes may spill over to other markets. They may affect the actions of other traders and policymakers.

\subsection{Implications for Policymakers}

Policymakers should make a concerted effort to harness the power of positive feedback trading when possible. Coordinated action by various central banks on November 30, 2011 sparked a rally in equity prices around the world in part due to triggering short covering. Policymakers need to be careful to avoid drawing incorrect inferences from speculative price moves. For instance, the Federal
Reserve's surprise 75 basis point rate cut on January 22, 2008 was precipitated, in part, by falling equity prices in Europe. As it turned out, European equity prices were falling due to the unwinding of Jerome Kerviel's rogue trading positions by Societe Generale. ${ }^{5}$

Policymakers must address the issue of whether additional safeguards are needed to protect the integrity of speculative markets from sharp price moves unrelated to the arrival of fundamental information. One dimension of market microstructure that should be considered is the frequency of trading. It is worth pointing out that the fragility of speculative markets to automated trading is partly a result of continuous markets.

\subsection{Implications for Practitioners}

Trading induced price changes or market microstructures that enhance volatility increase the risks for all market participants and change how they should trade and price securities. The regular occurrence of "extreme events" means that option prices should take the possibility of their occurrence into account. For instance, put options prior to the 1987 stock market crash were "underpriced."

\subsection{Implications for Academics}

Most prices reflect the interplay of supply and demand. It is worth repeating. Most prices reflect the interplay of supply and demand. For good or for ill, most market prices reflect the consensus view of market participants given current and prospective economic conditions and sentiment. However, mixed in with price changes driven by the arrival of new fundamental information or noise are price changes that are entirely trading induced. ${ }^{6}$

The fact that some of the largest extreme price moves are trading induced highlights the fact that trading is a game. Not all large price changes reflect new fundamental information (outside of game specific issues such as holdings by various market participants.) More research needs to be conducted on both predatory trading and positive feedback trading. 


\section{References}

Barron's, A Bad Two Weeks-A Wall Street Star Loses $\$ 840$ Million, November 2, 1987.

Bachelier, L. (1964). Theory of speculation, in P. Cootner (ed.), The Random Character of Stock Market Prices (Cambridge, Mass., MIT Press).

Black, F. (1986). Noise. Journal of Finance 41, 529-543.

Brunnermeier, M. K. and Pedersen, L. H. (2005). Predatory Trading. Journal of Finance 60, 1825-1863.

Camerer, C. F. (1989). Bubbles and Fads in Asset Markets: A Review of Theory and Evidence. Journal of Economic Surveys 3, 3-38.

Chamley, C. (2003). Dynamic Speculative Attacks. American Economic Review 93, 603-621.

Corsetti, G., Dasgupta, A., Morris, S., and Song, S. H. (2004). Does one Soros make a Difference? A Theory of Currency Crises with Large and Small Traders. Review of Economic Studies 71, 87-113.

DeLong, B. F., Shleifer, A., Summers, L. and Waldman, R. (1989). The Size and Incidence of Losses from Noise Trading. Journal of Finance 44, 683-696.

DeLong, B. F., Shleifer, A., Summers, L., and Waldman, R. (1990a). Positive Feedback Investment Strategies and Destabilizing Rational Speculation. Journal of Finance 45, 379-396.

DeLong, B. F., Shleifer, A., Summers, L. and Waldman, R. (1990b). Noise Trader Risk in Financial Markets. Journal of Political Economy 98, 703-738.

Evans, M., and R. Lyons (2002). Order Flow and Exchange Rate Dynamics. Journal of Political Economy 110, 170-180.

Fama, E. F. (1965). The Behavior of Stock Market Prices. Journal of Business 38, 34-105.

Fama, E. F. (1970). Efficient Capital Markets: A Review of Theory and Empirical Work. Journal of Finance 25, 383-417.

Flood, R. P. and Hodrick, R. J. (1994). On Testing for Speculative Bubbles. In "Speculative Bubbles, Speculative Attacks, and Policy Switching," edited by R.P. Flood and P.M. Garber (MIT Press, Cambridge, MA).

Jackwerth, J.C., and Rubinstein, M. (1996). Recovering Probability Distributions from Option Prices. Journal of Finance 51, 1611-1632.

Gürkaynak, R. S. (2008). Econometric Tests of Asset Price Bubbles: Taking Stock. Journal of Economic Surveys 22, 166 186.
Kendall. M. G. (1953). The Analysis of Economic Time Series, Part I: Prices. Journal of the Royal Statistical Society 96, 11-35.

LeRoy, S.F. (2004). Rational Exuberance. Journal of Economic Literature 42, 783-804.

Mandelbrot, B. (1963). The Variation in Certain Speculative Prices. Journal of Business 36, 394-419.

Marsh, T. and Rosenfeld, E. (1986). Nontrading, Market Making and Estimates of Stock Price Volatility. Journal of Financial Economics 15, 359-372.

McCormick, L. C. Yen Risk Reversals Climb to a NineMonth High Amid Options Hedging Demand. Bloomberg News, March 17, 2011.

http://www.bloomberg.com/news/2011-03-17/yenrisk-reversals-climb-to-a-nine-month-high-amid-optionshedging-demand.html.

Miller, M. H. (1989). Who Should Set Futures Margins? Review of Futures Markets 7, 398-404.

Osler, Carol L. (2002). Stop-Loss Orders and Price Cascades in Currency Markets. FRB of New York Staff Report No. 150. Available at SSRN: http://ssrn.com/ abstract=920687 or http://dx.doi.org/10.2139/ssrn.920687

Roberts, H. V. (1959). Stock Market Patterns and Financial Analysis: Methodological Suggestions. Journal of Finance 14, 1-10.

Ross, S. (1989). Information and Volatility: The NoArbitrage Martingale Approach to Timing and Resolution Irrelevancy. Journal of Finance 44, 1-17.

Samuelson, P. A. (1965). Proof that Properly Anticipated Prices Fluctuate Randomly. Industrial Management Review 6, 41-49.

Securities and Exchange Commission and Commodity Futures Trading Commission, 2010, Findings regarding the Market Events of May 6, 2010, September 30,

http://www.sec.gov/news/studies/2010/marketeventsreport.pdf.

Shiller, R. J. (2003). From Efficient Markets Theory to Behavioral Finance. Journal of Economic Perspectives 17, 83-104.

Spicer, J. High-Frequency Firm fined for Trading Malfunctions. Reuters News, November 25, 2011. http://www.reuters.com/article/2011/11/25/us-cmeinfinium-fine-idUSTRE7AO1Q820111125 
Webb, R. I. (2007) Trading Catalysts: How Events Move Markets and Create Trading Opportunities, (FT Press, New York).

Working, H. (1934). A Random Difference Series for use in the Analysis of Time Series. Journal of the American Statistical Association 29, 11-24.

Xydias, A. Volkswagen Overtakes Exxon as Most Valuable Company (Update1), Bloomberg News, October 28, 2008. http://www.bloomberg.com/apps/news?pid=newsarchiv e\&sid=ahQ8kYJVCpWQ.

Yam, J. (1998). Coping with Financial Turmoil, Inside Asia Lecture, Sydney Australia, Hong Kong Monetary Authority, November 23,

http://www.info.gov.hk/hkma/eng/speeches/speechs/ joseph/speech_231198b.htm.

1 Bachelier (1964) both observed that certain speculative prices appeared to fluctuate randomly and advanced an explanation for it in the early part of the 20th century. However, his contribution to the literature was largely unknown until the second half of the 20th century.

2 For reviews of some of the literature see Camerer (1989) (bubbles and fads); Flood and Hodrick (1994) ((tests of speculative bubbles); LeRoy (2004) (rational and irrational speculative bubbles); Gurkaynak (2008) (econometric tests of asset price bubbles); and Shiller (2003) (market inefficiencies and behavioral finance).

3 This situation was made worse by the fact that the State of Lower Saxony held $20 \%$ of VW and was unlikely to sell any of its holdings.

4 The market was already down several hundred points when the Flash Crash occurred. The decline in the market before the Flash Crash is sometimes mistakenly added to the decline that occurred during the Flash Crash.

5 Mr Kerviel lost $€ 1.4$ billion for Societe Generale. However, SocGen lost another $€ 3.5$ billion unwinding Mr. Kerviel's rogue trading positions.

6 In an analysis of large changes in the FX market, Osler [2002] argues that "Stop-loss [orders] propagated price cascades may help explain the well-known fat tails of the distribution of exchange rate returns, or equivalently the high frequency of large exchange rate moves." She also argues that the resulting "path dependence of exchange rates may also help explain why technical analysis has a track record of forecasting success while standard exchange rate models do not."

\section{Corresponding Author}

Robert I. Webb, McIntire School of Commerce, University of Virginia in Charlottesville, Virginia, USA.

Email: riw4j@comm.virginia.edu 